\title{
1. EARLY CRETACEOUS RUDIST FAUNA OF ALLISON AND RESOLUTION GUYOTS, MID-PACIFIC MOUNTAINS ${ }^{1}$
}

\author{
Nicola H.M. Swinburne ${ }^{2}$ and Jean-Pierre Masse ${ }^{3}$
}

\begin{abstract}
Rudists from Resolution and Allison guyots (Mid-Pacific Mountains), recovered during Leg 143 of the Ocean Drilling Program (ODP), are recorded from Barremian to Albian strata. Taxa present belong to the families Requieniidae, Monopleuridae, and Caprinidae. Radiolitidae are noticeably absent. The Barremian interval yielded only one determinable monopleurid rudist, Petalodontia. This occurrence is compatible with its known range in Europe and establishes a circum-global Tethyan distribution for this form. Early Aptian strata produced a rich and diverse fauna of primitive caprinids, corresponding in their evolutionary development to species known from Europe and America from beds of this age. A new species of Caprina, a closely related form, also probably from that genus, and a form of unknown genus are described. All these taxa have right valves with simple, rectangular canals developed mainly on the dorsal and anterior margins. Although there is some relationship between our forms and European and American caprinids endemism exists at the generic and specific levels. The Albian interval also yielded several types of caprinids, but of larger size and having systems of pallial canals different from those of the Aptian. Of particular interest is the occurrence of "Caprina" cf. mulleri, which was previously described by Hamilton (1956) from Cape Johnson Guyot, also in the Mid-Pacific Mountains. This distinctive form may be an indicator of a Pacific Province, or endemic center. A genus related to the coalcomanid genus Caprinuloidea, an American endemic, was also found at this level. This demonstrates some relationship between the Pacific and Caribbean regions at this time.
\end{abstract}

\section{INTRODUCTION}

Rudist bivalves are known from shallow-water carbonates, of Late Jurassic and Cretaceous age, that were deposited in tropical regions. In the Aptian-Albian interval they are well known from Europe, North and East Africa, the Middle East and Central Asia, and from North and Central America and Japan. Currently, few descriptions of rudists from the Pacific region are available. Those that exist are based on dredge material from which a few isolated forms have been recovered (Hamilton, 1956; Heezen et al., 1973; Ishii, 1985; Shiba, 1979, 1988). The description of rudists from Allison (Hole $865 \mathrm{~A}$ ) and Resolution Guyots (Holes 866A, 867B and 868A, see Fig. 1) in the Mid-Pacific Mountains during ODP Leg 143 is significant, therefore, for understanding the evolution and dispersal of this group.

Rudists undoubtedly played a part in the construction of the shallow-water carbonate edifices, which have grown over the original volcanic foundation of Pacific seamounts. Models of Cretaceous carbonate platform development tend to be based on the present-day situation in coral atolls, where an outer wave-resistant framework of some topographic relief protects an inner, muddy lagoonal depression. Rudists have been assigned much of the same role as that of modern corals in the construction of the reef framework. By drilling deep into the guyots and recovering examples of the facies, much can be learned about the role of rudists in the growth of Cretaceous carbonate platforms.

Rudists have potential as biostratigraphic markers when similar forms with known ranges are available for comparison. As we have almost no knowledge of rudist ranges in the Pacific, comparisons must be made to ranges of similar, perhaps not identical, forms in Europe, Africa, and the Americas.

\footnotetext{
1 Winterer, E.L., Sager, W.W., Firth, J.V., and Sinton, J.M. (Eds.), 1995. Proc. ODP, Sci. Results, 143: College Station, TX (Ocean Drilling Program).

${ }^{2}$ Dept. of Geology and Geophysics, University of California at Berkeley, CA 94720 , U.S.A.

Centre de Sédimentologie-Paléontologie CNRS-URA 1208, Université de Provence, Place Victor Hugo, F-13331, Marseille, Cédex 3, France.
}

Leg 143 scientists were fortunate in recovering samples that represent a significant part of the history of growth of the shallow-water carbonate cap of Resolution and Allison guyots. Potentially identifiable macrofossils were collected on board the ship and tentative determinations of the rudists were made (Swinburne in Sager, Winterer, Firth, et al., 1993), but in the absence of any comparative material and with only minimal literature. The following description supersedes preliminary remarks made in the first volume, and corrects some errors in sample numbers. The nonrudist macrofossils, which consist mostly of gastropods and some hydrozoans, have not as yet been described and a table of these specimen numbers is presented as an appendix.

Rudist determination from ODP material is difficult partly because the sample size is limited by the $5-\mathrm{cm}$ core diameter. Because complete rudist valves are commonly several tens of centimeters in diameter, we have complete sections only of the small forms. Exposures on the surface of drilling biscuits, as well as serial sections cut with a saw at the required angles, have been used to interpret threedimensional morphology and structural organization. We have few unequivocal examples of bivalved specimens. However, right and left valves can be distinguished in specimens of isolated valves by examining the teeth, sockets, myophoral organization, or coiling direction. Fragments of the valve walls are all we have for the larger forms, but for caprinid genera, this suffices to narrow the choice to one or a few possible genera. The preservation of the fragments is highly variable, but in several instances, original aragonite has been preserved, and growth lines can be seen around structures in the aragonitic part of the rudist shell.

Isolated rudist fragments occurred in several levels in the cores, but identifiable specimens were present at only three levels: one at the summit of Allison and Resolution guyots (Shipboard Scientific Party, 1993a, 1993c), one at a lower level at Resolution Guyot, Hole 866A (Shipboard Scientific Party, 1993b), and another at still lower level at Resolution Guyot, Hole 866A (see Fig. 1 for stratigraphic location of rudist-bearing levels). These stratigraphic levels have been dated primarily on the basis of foraminiferal biostratigraphy, but chemostratigraphy provides additional evidence for the age of the lower levels in Hole 866A. 
Resolution Guyot

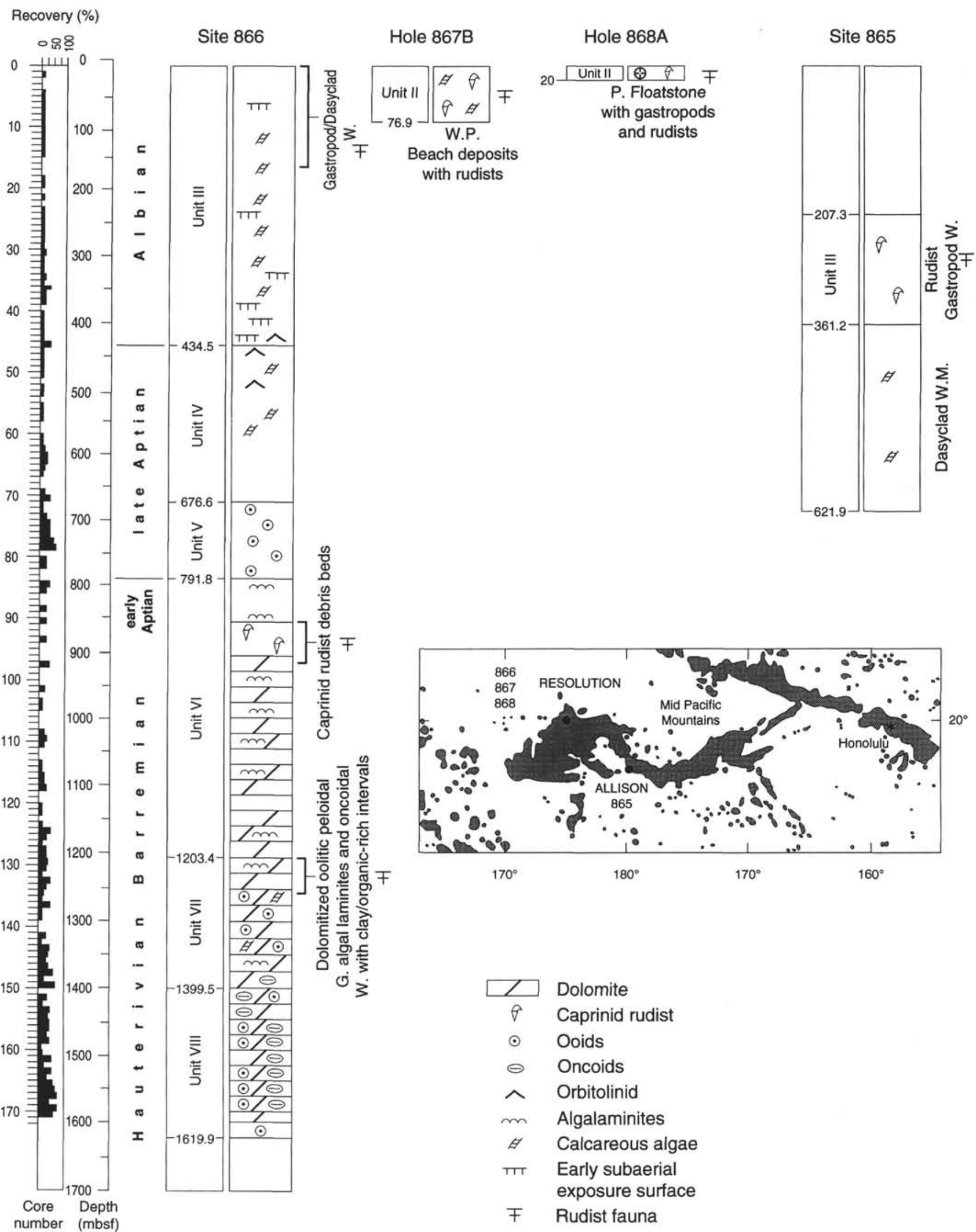

Figure 1. Location of Resolution and Allison guyots and the Mid-Pacific Mountains and stratigraphy of the corresponding sites with position of rudist levels. 


\section{SYSTEMATIC PALEONTOLOGY}

(Abbreviations: $\mathrm{LV}=$ left valve; $\mathrm{RV}=$ right valve.)

HIPPURITACEA Gray, 1848

REQUIENIIDAE Douvillé, 1914

Requienia Matheron, 1842

Chama ammonia Goldfuss, 1838, p. 205, fig. 3, pl. 15, figs. 1-2 (Subsequent designation of Matheron, 1842, p. 103, figs. 1-7).

Requienia cf. migliorinii Tavani, 1948

(PI. 1, Figs. 1-3)

1948 Requienia migliorinii Tavani, p. 26; pl. XI, figs. 12-14-16.

1949 Requienia migliorinii Tavani, p. 10.

?1956 Vermicularia sp. Hamilton, pl. 8, fig. 2, p. 63.

1973 Toucasia polygyra Alencaster, pl. 11-12, I, II, III, figs. 1-4.

1975 Requienia tortilis Mainelli, tav. 1, figs. 1-10; tav. 2, figs. 1-22.

1976 Requienia ef. migliorinii Tavani, Masse, pp. 235-236, pl. 15, fig. 10.

1983 Requienia aff. migliorinii Tavani, Chikhi-Aouimeur, text figs. 1a, 1b, 1c; pl. 1, figs. 1-3.

1986 Requienia sp. aff. migliorinii Tavani, Johnson et al., 1986, pp. 1-10, figs. 3 and 11 .

Material studied. Hole 865A, drilled near the center of Allison Guyot. Cores 28 and 35 (Subunit IIIA; rudist/gastropod wackestone, 621.9-870.9 mbsf, Shipboard Scientific Party, 1993a, pp. 122-123) contain numerous examples of the RV of a small requienid rudist (originally described in Shipboard Scientific Party, 1993a, p. 133 and Fig. 11, p. 125). The best samples are in pieces: Samples 143-865A-28R-1, 47-49 cm (ibid. Fig. 11, p. 25); 61-64 $\mathrm{cm} ; 66-68 \mathrm{~cm} ; 109-112 \mathrm{~cm} ; 113-116 \mathrm{~cm} ; 28 \mathrm{R}-\mathrm{CC}, 1-4 \mathrm{~cm}, 8-10 \mathrm{~cm}$, and $17-19 \mathrm{~cm} ; 35-\mathrm{CC}, 8-10 \mathrm{~cm}$.

Age. Subunit IIIA, the unit in which these rudists occur, is considered late Albian on the basis of the benthic foraminifers, notably: Cuneolina cf. pavonia d'Orbigny, Cuneolina parva Henson, Nezzazata isabellae Arnaud-Vanneau and Sliter, and Barkerina cf. barkerensis Frizzell and Schwartz (ArnaudVanneau and Sliter, this volume).

Description of material and generic and specific affinities. The material shows the presence of a small form having one helicospiral valve that spirals up to three whorls. The external shell layer is preserved as a brown, organicrich calcite, 1 to $2 \mathrm{~mm}$ thick. With these characteristics, the form is unequivocally a requienid.

Distinction at the generic level is based primarily upon the myophoral apparatus that forms part of the inner, originally aragonitic layer. Preservation of this layer is variable in these specimens; in some this layer was removed early in diagenesis, and the void filled in by micrite; in others, it has been bored by sponges and only the casts of these remain; in some, fortunately, this layer has been recrystallized to sparite, and so its shape is visible in section. In other examples, the outer calcitic layer has become physically detached from the inner aragonitic layer during burial. Where the shape of the inner layer is still visible, we can in no instances see a myophoral ledge, which would indicate either Toucasia or Apricardia. Thus, the genus is Requienia.

The small size of the form (valve diameter, 7-11 $\mathrm{mm}$ and height max., 15 $\mathrm{mm}$ ) and the low rate of whorl expansion strongly suggest its affinities with Requienia migliorinii Tavani. The circular-oval whorl cross section (i.e., absence of keel) is also commensurate with this identification. However, we have only the left valve (which spirals clockwise when viewed from the umbo side, from the umbo outward), by far the larger of the two, and which was embedded in the sediment. $R$. migliorinii has a small operculiform upper, right valve that we have not seen in these specimens.

Therefore, we can only suggest, rather than confirm, that our form belongs to the species $R$. migliorinii. The species is recorded in Europe in the upper Barremian of Provence (Masse, 1976); ?Albian of Somalia (Tavani, 19481949); upper Aptian of Algeria (Chikhi-Aouimeur, 1983); Albian of central Italy (Mainelli, 1975); Barremian to Albian, central and southern Italy, (Mainelli, 1975, Luperto Sinni and Masse, 1986 and Masse, unpubl. data); Barremian to Albian of Oman (Masse, unpubl. data). In the Caribbean Province, $R$. migliorinii is known from Oaxaca, southwest Mexico (Alencaster, 1973 ) in beds that also contain the rudist Coalcomana ramosa (Boehm). $C$. ramosa is considered to be of early to middle Albian age from its occurrences in Texas (Coogan, 1973, 1977; Young, 1984) and in Mexico (Scott and Gonzales Leon, 1991; Alencaster and Pantoja Alor, 1986). R. migliorini is also found in the El Abra region in North Central Mexico in strata of Albian age (Johnson et al., 1986).
The species has probably been recorded previously from the Pacific region by Hamilton (1956) from the material dredged from Cape Johnson Guyot in the Mid-Pacific Mountains. Hamilton figured a specimen which he called "Vermicularia," presuming it was a gastropod, which seems to be a fine three-dimensional example of the $\mathrm{LV}$ of the rudist $R$. migliorinii.

$$
\begin{gathered}
\text { MONOPLEURIDAE Munier-Chalmas, } 1873 \\
\text { Petalodontia Pocta, } 1889 \\
\text { Hippurites germari Geinitz, } 1840 \\
\text { Petalodontia } \text { sp. indet. } \\
\text { (PI. 1, Fig. 4) }
\end{gathered}
$$

Material studied. Sample 143-866A-131R-1, 80-84 cm (Subunit VIIA; brown dolomitized oolitic peloidal grainstone, algal laminites, and oncoidal wackestone with clay/organic-rich intervals, 1203.4-1251.6 mbsf; Shipboard Scientific Party, 1993b, pp. 199-200) from marginal platform facies of Resolution Guyot, Hole 866A. This piece contains one bivalved specimen in one transverse and one longitudinal section (not previously described in detail).

Age. Benthic foraminiferal evidence favors a Hauterivian age for Subunit VIIA, in which this rudist is found; chemostratigraphic evidence points to a Barremian age. Benthic foraminifers found in this unit are Campanellula capuensis De Castro, Melathrokerion cf. valserinensis Bronnimann and Conrad, Decussoloculina cf. mirceai Neagu, Valvulineria? sp. 1 Arnaud-Vanneau, and Vercorsella wintereri Arnaud-Vanneau and Sliter (Arnaud-Vanneau and Sliter, this volume). An age of Barremian is compatible with the presence of all of these foraminifers, with the exception of $C$. capuensis, which, if the diagnosis is correct, would imply a Hauterivian age for the unit. A comparison of the carbon isotope record of Site 866 with isotopic curves from the TethyanAtlantic would place Subunit VIIA in the Barremian (Jenkyns, this volume).

Description of material and familial affinity. In transverse section, the $\mathrm{RV}$ is roughly circular and slightly compressed in an anterio-posterior direction, with gently protruding radial bands and a depressed interband. The RV is approximately cylindrical. An external primary calcitic layer 0.5 to $1 \mathrm{~mm}$ thick is visible. The specimen has been partly crushed in the dorsal region, but a small triangular ligamentary crest, corresponding to an external groove, can be discerned. Two sediment-filled sockets and the remains of an arcuate central tooth are visible. The anterior socket is elongated in an antero-ventral direction; the posterior is kidney-shaped and lies with its long axis in a anterio-posterior orientation. There are no accessory cavities, a feature that implies the form is probably a monopleurid, rather than a caprotinid.

The LV is capuloid in shape and demonstrates what we have interpreted to be a vertical myophoral plate. This feature conforms to Petalodontia, rather than Monopleura, because Petalodontia has one vertical myophoral plate, whereas Monopleura has myophores parallel to the commissure.

Petalodontia is a genus that is currently not known from strata older than Barremian (Douvillé, 1918).

\section{CAPRINIDAE d'Orbigny, 1850 \\ CAPRININAE Douvillé, 1888}

Caprina d'Orbigny, 1822

C. adversa d'Orbigny, 1848, pl. 536. (Subsequent designation of Paquier, 1905, p. 69).

\section{Caprina sp. 1}

(PI. 1, Figs. 5, 6)

Material studied. Two samples, 143-866A-94R-1, 16-19 cm, and 95R-1, $27-30 \mathrm{~cm}$, from the marg nal platform facies of Resolution Guyot (Subunit VIB; caprinid rudist debris beds, 859.2-917.0 mbsf; Shipboard Scientific Party, 1993b, p. 194 and p. 199). Both are complete sections of RVs (originally described in Shipboard Scientific Party, 1993b, p. 213 along with specimens now attributed to Caprina (?) sp. 2 and Caprinid indet. 1, see below).

Age. All evidence points to a Barremian to early Aptian age for Subunit VIB. The occurrences of the benthic foraminifers: Protopeneroplis sp., Nezzazata? sp. C Arnaud-Vanneau and Sliter, Falsurgonina? sp. and Neotrocholina $\mathrm{cf}$. friburgensis Guillaume and Reichel, suggest a Barremian to early Aptian age (Arnaud-Vanneau and Sliter, this volume) for this subunit. The occurrence of Caprina sp. 1 and other probable species, of the genus Caprina would favor an early Aptian age more than a Barremian age, based on the distribution of that taxon in Europe (Masse and Philip, 1986). A comparison of the carbon isotope record of Site 866 with isotopic curves from the Tethyan-Atlantic would place Subunit VIB at approximately the Barremian/ Aptian boundary (Jenkyns, this volume). 
Description of material and probable generic affinity. The form is approximately circular in transverse section. In the inner, originally aragonitic layer, there is a single row of rectangular canals. (These are now preserved by micritic envelopes) (Shipboard Scientific Party, 1993b, p. 199). The canals are not divided transversely. A small ligamentary crest (invagination of the outer calcitic layer) marks the dorsal side of the specimens and this corresponds to a shallow external groove. The features that distinguish the RV are the thin $(<1$ $\mathrm{mm}$ ) external calcitic layer and two sockets. The canal system of the RV extends from the ligamentary crest in a posterior direction, around the outer side of the posterior socket, and terminates near the ventral margin. The posterior socket is smaller than the anterior socket. The central tooth must be very small. The one specimen of the LV has a vertical partition that separates the posterior socket from a posterior cavity.

The single row of rectangular canals on the posterior side is the most important diagnostic feature. Caprinid genera recorded from Lower Cretaceous strata that have simple canals in the RV are Caprina d'Orbigny, Amphitriscoelus Harris and Hodson, Praecaprina Paquier, Neocaprina Plenicar, Offneria Paquier and Pachytraga Paquier (a caprinid, rather than a caprotinid, according to MacGillavry, 1937).

However, with the exception of Caprina, all the genera mentioned above are approximately symmetrical with respect to the ligament in the disposition of cavities and pallial canals. Moreover, in Amphitriscoelus, the central tooth is large with a posterior protuberance (a feature typical of coalcomanids) and the posterior socket is larger than the anterior socket; in Offneria and Neocaprina, the canal system extends anteriorly into the ventral region; moreover, in Offneria, the canals are divided transversely; Praecaprina has a system of canals developed antero-ventrally with respect to the anterior cavity, and the posterior cavity is not subdivided into canals; in Pachytraga, the posterior cavity is not subdivided into canals either.

Therefore, Caprina is the only known genus to which this form could belong. It must be related to the other four Aptian species in that they are all small, primitive forms with few, simple rectangular canals mostly restricted to the dorsal area (at least in the RV): C. douvillei Paquier (1905), C. parvula Douvillé (in Douvillé and O'Gorman, 1933), C. andersoni (Harris and Hodson, 1922), and C. plumensis Harris and Hodson (1922). However, our species is significantly smaller and simpler in the distribution and structure of its canals than the two Caribbean species $C$. anderson $i$ and $C$. plumensis, and the canals are more developed than in the French species $C$. parvula.

As this is a new species, it will be described formally in another work.

Caprina(?) sp. 2

(Pl. 1, Figs. 7A, 8, and 9)

Material studied. The smaller of the two forms in Sample 143-866A-97R$1,27-30 \mathrm{~cm}$, and the specimen in Sample 143-866A-97R-1, 36-38 cm, from the marginal platform facies of Resolution Guyot (Subunit VIB; caprinid rudist debris beds, 859.2-917.0 mbsf; Shipboard Scientific Party, 1993b, p. 194 and p. 199). Both are entire transverse sections of RVs with six sections of 97R-1, $27-30 \mathrm{~cm}$, and three sections of 143-866A-97R-1, 36-38 cm (originally described in Shipboard Scientific Party, 1993b, p. 213, along with other specimens with rectangular canals, some of which are included in Caprina sp. 1 and Caprinid indet. 1).

Age. Probably early Aptian (for details see remarks under Caprina sp. 1).

Description of material and probable generic affinity. The specimen in Sample 143-866A-97R-1, 36-38 cm, which can be seen in four transverse sections, is subcircular in outline and significantly flattened in a dorso-ventral direction. In the apical region, it is fixed to another shell on its anterior face, which is flattened, and the posterior remains convex. It is a small form having a diameter of $15 \mathrm{~mm}$, a length of 30 to $40 \mathrm{~mm}$, but fairly strongly coiled, and we see a $17 \mathrm{~mm}$ depth to the valve. The specimen in Sample 143-866A-97R-1, $27-30 \mathrm{~cm}$, is slightly smaller, is also attached to a shell, and shows the same external shape.

There is an obvious, thin, outer layer $<1 \mathrm{~mm}$ thick, of primary calcite, invaginated in the dorsal region to form a ligamentary crest, triangular in cross section. Sparite-filled sockets are present both on the anterior and posterior sides and are approximately oval in shape. The anterior socket has some small indentations on the dorsal side, but otherwise, the precise shape of the sockets is not easy to determine, because of the poor preservation of the material. The specimen in Sample 143-866A-97R-1, 27-30 cm, has an anterior socket that is better preserved and is almost rectangular in shape, also with denticular protrusions. The posterior socket still contains a tooth that fills most of the space.

A well developed system of rectangular canals on the dorsal and anterior sides of the specimen envelopes the socket. Near the ligament, the canals are relatively narrow and orientated radially, but they are broader in more anterior regions. On the posterior side, there are few canals and those that exist are small in diameter and approximately circular in section. No canals exist on the ventral side, nor on the antero-ventral side of the specimen near the apex (alongside the attachment surface).

The form does not have the diagnostic characteristics of a coalcomanid because the central tooth does not protrude obviously into the posterior accessory cavity. Moreover, the posterior cavity probably functioned essentially as a socket, and any "accessory" part is very limited in size. This situation is not the case for coalcomanids, which have a relatively large posterior accessory cavity.

Comparisons with any member of Caprininae are difficult because our form has small canals that envelope the posterior cavity as well as the relatively small posterior cavity both of which are characteristics not known in this subfamily. It is not a member of the genus Praecaprina because that form has essentially no canals in the RV. It is not an Offneria because the canals are mainly developed on the dorsal side and Offneria has canals around the entire margin.

However, its asymmetry in disposition of canals in some ways resembles primitive members of the genus Caprina, such as $C$. parvula Douville (Douvillé and O'Gorman, 1933; Masse, unpubl. data).

\section{Caprinid indet. 1}

$$
\text { (Pl. 1, Fig. 7B) }
$$

Material studied. The larger specimen in Sample 143-866A-97R-1, $27-30 \mathrm{~cm}$, seen in six transverse sections, from the marginal platform facies of Resolution Guyot (Subunit VIB; caprinid rudist debris beds, 859.2-917.0 mbsf; Shipboard Scientific Party, 1993b, p. 194 and p. 199). The specimen is a RV. (It was originally described in Shipboard Scientific Party, 1993b, p. 213, along with specimens now attributed to Caprina sp. 1 and Caprina(?) sp. 2, see above).

Age. Probably early Aptian (for details see remarks under Caprina sp. 1).

Description of material and probable generic affinity. The valve is approximately circular in outline, but slightly flattened on the ventral and antero-ventral sides. The RV is characterized by an outer, primary calcitic layer $(<1 \mathrm{~mm}$ thick) showing fine costae and two sockets. The form has a thick, originally aragonitic, inner layer with pallial canals. Two sockets and one central tooth are symmetrically oriented with respect to the ligamentary crest, which is triangular in section.

The presence of the entire myocardial apparatus tells us much about the generic affinities of this form. The central tooth is arcuate (as in all caprinids, coalcomanids, monopleurids, and primitive caprotinids) and envelopes the anterior cavity (thus providing a method for orienting the specimen). In this form, the anterior socket is larger than the posterior. Moreover, there is no posterior cavity, but instead, the area situated ventrally to the posterior socket is occupied by pallial canals. Pallial canals are present both anteriorly and posteriorly in rows on the outside of the sockets, and the system also extends ventrally. The exact shape of the canals is hard to determine because of the poor preservation of the specimen, but the few canals observed appear to be rounded, with thick intervening walls, rather than neatly juxtaposed.

The absence of a protrusion into the posterior socket on the posterior side on the central tooth indicates that this is not a coalcomanid. Therefore, comparisons must be sought with known caprinid genera. The presence of canals around the entire margin of the RV excludes the genera Praecaprina and Caprina, and the only form that does have this characteristic is Offneria. However, our form is unlike Offneria in that Offneria has a large posterior accessory cavity as an extension of the posterior socket. Moreover, in Offneria, the canal system is made of plates, rather than tubular holes, inside a massive aragonitic shell wall. This form, therefore, belongs to an unknown genus.

\section{Caprinid fragments of questionable affinity}

$$
\text { (Pl. 1, Fig. 10, Pl. 2, Fig. 1) }
$$

Samples 143-866A-92R-1, 16-19 cm, and -93R-1, 1-3 cm, contain numerous fragments of valve walls having rectangular canals (Pl. 1, Fig. 10) preserved as micritic envelopes. The specimens come from Subunit VIB, which also contains the caprinids mentioned above: Caprina sp. 1, Caprina(?) sp. 2 (preserved in similar fashion), and Caprinid indet. 1. (preserved as recrystallized calcite).

Several other fragments of caprinids having rectangular canals also come from this unit but are too small to be worth a separate description. The fragments in Samples 143-866A-95R-1, 17-19 cm; 143-866A-94R-1, 70-73 $\mathrm{cm}$; and 143-866A-94R-1, 12-15 cm, showing rectangular canals in one or two rows, are forms of the same size as Caprina(?) sp. 2 and Caprinid indet. 1 and may belong to one of these or to another form. 


\section{COALCOMANINAE Coogan, 1973}

Coalcomanid indet. 1

(Pl. 2, Figs. 2 and 3)

Material studied. Sample 143-868A-4R-1, 94-100 cm, from the top of Resolution Guyot in marginal platform facies (Subunit IIC; 0-20.3 mbsf, Shipboard Scientific Party, 1993c, pp. 278-279). The sample contains most of a RV with one transverse, one oblique and one longitudinal section. The form was originally described in Shipboard Scientific Party (1993c, p. 284 and Fig. 12 , p. 286) as $867 / 8$ type 3.

Age. Benthic foraminifers suggest a late Albian age for Subunit IIC (Arnaud-Vanneau and Sliter, this volume). The relevant forms are Nezzazata sp. A Arnaud-Vanneau and Sliter, Nezzazata isabellae Arnaud-Vanneau and Sliter, Cuneolina parva Henson, Cuneolina cf. pavonia d'Orbigny, Pseudonummoloculina sp. X Arnaud-Vanneau and Sliter, Trocholina lenticularis Henson, Trocholina cf. odukpaniensis Dessauvagie, and Barkerina cf. barkerensis.

Description of material and generic affinity. The form is roughly circular in transverse section, and slightly flattened in both the dorsal and ventral regions, with a maximum diameter of about $50 \mathrm{~mm}$ (visible in our incomplete sample). The valve coils for about half a whorl. The canal-bearing layer is fairly thick (5 mm average) and, in places, still consists of the original aragonite. There is no external calcitic layer preserved. The sockets are large, thus leaving little space for the body chamber. Relatively thick tabulae are present in the body chamber.

The dentition is key to the diagnosis of a RV. We have interpreted the specimen to show two sockets, which still contain the teeth of the LV. The posterior cavity, which represents both the socket and an accessory cavity, is arcuate and parallels the external shell outline. Pallial canals are present on the external side of this cavity. The RV central tooth is large, compact (without the cellular structure possessed by some, but not all the species of the genus Caprinuloidea, for example), and arcuate, with the concavity facing anteroventrally. The tooth protrudes into the posterior accessory cavity. These two characteristics are diagnostic for the subfamily Coalcomaninae (Coogan, 1973) because in the European Caprininae, the posterior cavity itself is subdivided into canals, and the tooth does not have a strong posterior protrusion. A narrow and relatively long ligamentary cavity runs approximately perpendicular to the dorsal margin.

Canals are present around the entire margin, apart from short regions on the ventral side, and, dorsally, on either side of the ligamentary cavity in basal sections. The canals are pyriform on the dorsal and posterior sides and polygo$\mathrm{nal} /$ irregular in two rows on the antero-ventral margin. The canals on the anterior, but not the posterior, side are subdivided transversely. The pyriform shape of most of the canals entirely excludes Amphitriscoelus Harris and Hodson, where they are trapezoidal/rectangular. The simple pyriform canals do not resemble those of Coalcomana Harris and Hodson, where the complex system of pyriform canals is constructed from a series of progressively bifurcating plates (Douvillé, 1900). The shape of the canals on the anterior side excludes all other known advanced coalcomanids, apart from Caprinuloidea Palmer. However, in Caprinuloidea, the canal system again is far better developed, with pyriform canals on the outside of the polygonal canals.

The relatively poor and irregular development of the canal system, presence of pyriform and polygonal/irregular canals in different portions of the valve, and the absence of canals from the ventral margin are characteristics that suggest that this is a primitive coalcomanid of unknown genus. It will be formally described in another work.

The most primitive members of the genus Caprinuloidea in the group $C$. perfecta Palmer of Coogan (1977), which are probably the forms most closely related to our specimen, are known from the American Gulf Coast, Mexico, and the Caribbean (Coogan 1973, 1977; MacGillavry, 1937; Scott, 1981) in early to late Albian.

Subfamily indet.

"Caprina" cf. mulleri Hamilton, 1956

(PI. 2, Figs. 4 and 5; Pl. 3, Figs. 1-3)

Material studied. Several samples from the top of Resolution Guyot at Holes 867B and 868A in marginal platform facies (Unit II; 0.3-76.9 (867B) and 0-20.3 (868A) mbsf, Shipboard Scientific Party, 1993c, p. 278). This description is based on specimens in Samples 143-868A-1R-1, 134-140 cm (complete transverse section of LV with part of the myocardial apparatus); $-4 \mathrm{R}-2,98-102 \mathrm{~cm}$ (oblique-longitudinal section of bivalved specimen with myocardial apparatus); $-1 \mathrm{R}-2,4-8 \mathrm{~cm}$ (complete transverse section of LV); and $-4 \mathrm{R}-1,7-9 \mathrm{~cm}$ (unknown valve showing some of myocardial apparatus in oblique section). Numerous fragments of valve walls having canals of the same shape probably also belong to this form, notably in Samples 143-868A-4R-1, $105-107 \mathrm{~cm}$, and $-5 \mathrm{R}-1,60-61 \mathrm{~cm}$. The form was originally described in Shipboard Scientific Party (1993c, pp. 282-283) as 867/8 type 1b.

Age. late Albian (for details see remarks under Coalcomanid indet. 1).

Description of material. The specimen in Sample 143-868A-1R-1, $134-140 \mathrm{~cm}$ (Pl. 2, Fig. 4) consists of a conical sediment-filled body chamber, surrounded by the remnants of a valve wall, mostly dissolved, but still demonstrating the presence of canals. The body chamber spirals for approximately about half a whorl in a helicospiral, the direction of which implies the specimen is a LV. Thus, the valve is capuloid in shape and has a diameter of $60 \mathrm{~mm}$ and a height of $20 \mathrm{~mm}$. This specimen provides evidence for canals in the valve wall around the anterior, posterior, and ventral margins (the dorsal margin is too poorly preserved).

Sample 143-868A-1R-2, 4-8 cm, shows most of a LV (diagnosed because of the coiling direction) having canals around most of the circumference. Sample 143-868A-5R-1, 60-61 cm (PI. 2, Fig. 5) is a large fragment of a coiled valve, seen in longitudinal to oblique section on the surface of the sample, with the body cavity preserved as a void. Pyriform canals can be seen throughout the valve wall. On one side of the specimen, a ledge that gently inclines toward the interior of the shell projects into the (empty) body cavity. It is separated from the valve wall by an outer furrow. This must be part of a myophoral support.

Sample 143-868A-4R-2, 98-102 cm (Pl. 3, Fig. 1) contains a fragment having the small body chamber preserved as a void and demonstrating the coiling direction, which diagnoses this as most of a RV, with one tooth from the LV still in the socket. Both of the teeth are prominent, although that in the LV is longer. The specimen coils for about half a whorl in a helicospiral so that the body chamber can be seen in transverse section and the teeth in longitudinal section on the same surface. The RV in this specimen has a maximum diameter of about $50 \mathrm{~mm}$, a height of about $40 \mathrm{~mm}$, and the $\mathrm{LV}$ tooth at $23 \mathrm{~mm}$ long protrudes significantly into the RV. The pyriform canals on the ventral margin confirm its affinity with the other specimens. From these two specimens, it is clear that the form has identical canals in both valves around the entire valve margin.

The specimen seen in Sample 143-868A-4R-1, 7-9 cm (Pl. 3, Fig. 2) shows a longitudinal section of fragment of a canaliculate valve $(30 \mathrm{~mm}$ in diameter, with a maximum height of $11 \mathrm{~mm}$ ) with a tooth and socket and the tooth of the other valve still in the socket. If we interpret the main valve present in this specimen as a RV, then the cross section of the myocardial apparatus strongly resembles that of Caprina mulleri Hamilton.

These specimens, together with the loose fragments, all show similar canals of 5 to 8 per centimeter and length/width ratios generally of less than three.

The shape of the canals is reminiscent of the LV of the genus Caprina, but particularly of the two isolated valves described by Hamilton (1956) as Caprina mulleri and C. mediopacifica. Hamilton's interpretation of these as LVs, rather than RVs, was mainly based on the occurrence of the canals, which are similar to those of the LV, but not of the RV. However, the coiling direction of the valves suggest RVs rather than LVs. Hamilton's specimens thus cannot belong to the genus Caprina because this has only poorly developed, irregular pallial canals in the RV. Moreover the two species C. mulleri and C. mediopacifica are probably synonymous. A re-description of "Caprina" mulleri as a new genus using Hamilton's specimens, and other new material dredged from Pacific guyots, is in progress. In our specimens, the presence of pyriform canals around the entire margin of the RV, as well as the LV, the strong coiling of both valves, and the elongate nature of the RV tooth and one of the LV teeth, all suggest an affinity between our specimens and "Caprina" mulleri. We are also uncertain at this point in time whether this taxon belongs to the Subfamily Coalcomaninae, or Caprininae.

\section{Caprinid indet. 2}

(PI. 3, Figs. 4-6)

Material studied. Three samples from the top of Resolution Guyot, Holes $867 \mathrm{~B}$ and $868 \mathrm{~A}$, in marginal platform facies (Unit II; 0.3-76.9 (867B); and 0-20.3 (868A) mbsf, Shipboard Scientific Party, 1993c, p. 278). Sample 143-867B-1R-1, 80-95 cm (Pl. 3, Fig. 4) contains a large fragment of a large LV having a vertical lamina; Sample 143-868A-2R-1, 5-9 cm, contains a fragment of valve wall and one valve having a narrow lamina; $143-868 \mathrm{~A}-2 \mathrm{R}-1$, $89-103 \mathrm{~cm}$ (Pl. 3, Fig. 5, 6) fragment of valve wall. This form was described in Shipboard Scientific Party (1993c, pp. 282-283) as 867/8 type 1a, along with some other specimens, now placed with "Caprina" cf. mulleri.

Age. late Albian (for details see remarks under Coalcomanid indet. 1).

Description of material. Sample 143-867B-1R-1, 80-95 cm contains a $10-\mathrm{cm}$-long fragment of a large cylindrical-conical valve, which must have been $>10 \mathrm{~cm}$ in diameter. The valve wall thickness varies from 11 to $17 \mathrm{~mm}$, and we have interpreted the thicker wall as being toward the top of the 
specimen, which implies that the apex pointed downward in the core. Given the cylindrical nature of the entire valve, it is unlikely that this is a LV that fell vertically into the sediment. On this basis, it is a RV in life position.

Canals are present throughout this fragment. They are pyriform in shape (three to six per centimeter) and, in places, the canal walls bifurcate once and rarely, twice. In longitudinal section, there are no partitions to these canals. A narrow, relatively long, vertical plate is attached to the valve wall. Its narrow shape suggests that it is a partition that separates an accessory cavity from the body chamber, rather than the margin of a socket. The end of the partition must be attached to the ventral side of the valve. Thus, the form possesses a posterior accessory cavity,

A specimen in Sample 143-868A-2R-1, 5-9 cm, is a fragment of valve wall having canals of the same size as the previously described specimen (but not showing bifurcations), but possessing the thin lamina attached to the valve wall that extends into the body chamber. A considerable amount of original aragonite is preserved in this piece.

Sample 143-868A-2R-1, 89-103 cm, contains a large fragment of valve wall having canals of the same diameter. In general, therefore, there are three to five canals per centimeter with length-to-width ratios of $>3$ in a valve wall of about $13 \mathrm{~mm}$ in diameter.

The canals in this form are pyriform in shape, as are those of "Caprina" cf. mulleri; both forms have canals in the RV. However, the much larger size, the cylindrical-conical, rather than capuloid, shape, the presence of the vertical lamina in the RV, and polyfurcations of the radial partitions, are not known in Hamilton's form. This caprinid therefore is undoubtedly different at the specific level from "Caprina" cf. mulleri and perhaps at the generic, too, because of the importance of the myophoral characteristics. The shape of the canals in the RV, and the two orders of bifurcations of the intervening walls, are features reminiscent of two coalcomanid genera: Planocaprina and Coalcomana. In the absence of a transverse section of the RV, it is not possible to observe the shape of the central tooth, a feature that distinguishes the two subfamilies Coalcomaninae and Caprininae. We cannot, therefore, give a firm generic attribution to this form.

\section{Caprinid indet. 3}

Another caprinid was described in Shipboard Scientific Party (1993c, pp. $283-284$ ) as $867 / 8$ type 2 . Two specimens now are included in this category: a fragment in Sample 143-868A-4R-1, 7-9 cm (which contains significant aragonite) and a large part of an unknown valve in Sample 143-867B-1-2, $87-90 \mathrm{~cm}$. Both have rectangular-oval pallial canals. We consider this form to be too poorly known to be worth a serious description.

\section{CONCLUSIONS}

\section{Biostratigraphy}

Petalodontia was found in Hole 866A on Resolution Guyot in Subunit VIIA in strata that is most likely of Barremian, rather than Hauterivian, age. A Barremian age for this specimen would fit with its currently known range (Douvillé, 1918).

The main rudist level in the lower part of Hole 866A, Resolution Guyot forms Subunit VIB. A primitive new species of Caprina, a closely related form also placed in that genus, and an indeterminate caprinid were identified from strata at this level.

These caprinids resemble other early Aptian forms. Caprina sp. 1 is a primitive, and currently undescribed species and the most closely comparable forms have been described from the early Aptian of Europe (Paquier, 1905; Douvillé and O'Gorman, 1933) and the Caribbean (Harris and Hodson, 1922; Skelton, 1982; Rojas et al., 1992). The evidence from the rudists for the age of this level being most probably early Aptian is therefore in agreement with both of the other age estimates.

One biostratigraphically useful form, a new, primitive coalcomanid genus resembling Caprinuloidea, came from the top of Resolution Guyot at Hole 868A, from Subunit IIC. The most closely related forms are those of the Caprinuloidea perfecta group of Coogan (1977) from the American Gulf Coast, Mexico, and the Caribbean (Coogan 1973, 1977; MacGillavry, 1937; Scott, 1981) that range from early, possibly to late Albian. Benthic foraminifers from the top of this guyot at Holes 866A, 867B, and 868A suggest that the age of the uppermost strata is late Albian (Arnaud-Vanneau and Sliter, this volume). Our new genus of coalcomanid would fit better with a slightly older age assignment, but is not grossly incompatible.

Allison Guyot yielded numerous specimens of the rudist Requienia cf. migliorinii in Hole 865A, Subunit IIIA. This level has been reliably dated as late Albian, using benthic and planktonic foraminifers (Arnaud-Vanneau and Sliter, this volume; Sliter, this volume). As this requieniid species is recorded in Europe/Africa and the Americas in strata of inner platform settings of Barremian to late Albian age, its occurrence at Allison Guyot in strata of late Albian age is not surprising.

\section{Paleobiogeography}

Resolution and Allison Guyots are thought to have originated in the southern hemisphere between paleolatitudes $12^{\circ}$ and $29^{\circ} \mathrm{S}$, probably between $12^{\circ}$ and $17^{\circ} \mathrm{S}$ (Sager, Winterer, Firth, et al., 1993). Rudists are not known in the Southern Hemisphere of the early Cretaceous of the Caribbean Province, although they are known from Africa (Somalia). The guyots' fauna contains the same elements (rudists, larger benthic foraminifers, dasycladacean algae and colonial corals) as the platform carbonate deposits of the northern hemisphere, although there are differences at the generic and even familial level.

Aptian-Albian rudists have a circum-global Tethyan distribution (Masse, 1992). In Aptian times, the fauna was, broadly speaking, more cosmopolitan at the generic level (Coates, 1973; Kauffman, 1973; Skelton, 1982; Masse and Rossi, 1987) than it was during the Albian. There are two exceptions to this: first, restriction of one genus, Glossomyophorus, to regions representing areas from the southern margin of Mediterranean Tethys (Masse, 1985 and Masse, unpubl. data); second the Caribbean region contains one distinctive endemic genus, Amphitriscoelus (Skelton, 1982). This genus is the most primitive known member of the caprinid subfamily Coalcomaninae (Coogan, 1977), which is endemic to the Caribbean Province. Except for Amphitriscoelus, the other six known coalcomanid genera are Albian forms. The Caribbean Province thus demonstrates a significant amount of endemism at the generic level from the European and African regions from Albian time onwards.

The early Aptian caprinids obtained from Resolution Guyot have simple canals similar to those known from coeval strata in Europe (Paquier, 1905; Douvillé and O'Gorman, 1933) and the Caribbean Province (Harris and Hodson, 1922; Skelton, 1982; Rojas et al., 1992). One circum-global Tethyan genus, Caprina, is definitely recorded, but most of the other specimens could not be placed in known genera. Therefore, the Pacific fauna so far recorded shows some endemism at the specific and generic levels. We did not find any coalcomanid that would have demonstrated a close relationship between the Pacific and the Caribbean provinces in early Aptian time.

The late Albian fauna contains one circum-global Tethyan element, Requienia cf. migliorinii, an unknown coalcomanid genus related to Caprinuloidea, and one form so far recorded only from the Pacific, "Caprina" cf. mulleri. The occurrence of a coalcomanid is highly significant, as it shows a connection between the Pacific area and the Caribbean Province already existed prior to Campanian time (contrary to the model of Skelton, 1988). "Caprina" cf. mulleri, described by Hamilton (1956) from Charlie Johnson Guyot, is also now known from several other guyots across the Pacific (Swinburne and Masse, unpubl. data) and seems to be a genus endemic to the Pacific. A notable absence from these Pacific guyots in strata of late Albian age are any representatives of the family Radiolitidae (which evolved in the late Aptian). Radiolitid debris is relatively easy to recognize in thin section, and it was not noted in any sediments at either guyot. (The one possible example of a piece of radiolitid found on board the ship, which was a loose piece seen in a core, is not considered by these authors to have been a radiolitid.) Given the range of facies that were encountered, the absence of radiolitids is not likely to have resulted from unsuitable paleoecological conditions, and we favor a paleobiogeographic explanation. 
With the current state of knowledge we therefore would conclude that during Early Aptian times, the Pacific area was connected with the rest of Tethys, given the occurrence of some circum-global Tethyan elements, but also was partially isolated and developed endemic genera and species. During late Albian time, the Pacific undoubtedly was exchanging faunas with the Caribbean Province, as the subfamily Coalcomaninae is common to both. However, the Pacific fauna are also sufficiently unique, containing several distinctive endemic genera, that they may warrant construction of a new Pacific Province or endemic center.

\section{Paleoecology}

In the pre-cruise literature, Sites 866,867 , and 868 , drilled near the margin of Resolution Guyot, were described as reefal sites, with Site 866 being "distal back-reef," and Site 867 "reef crest" and Site 868 as "forereef crest" (see location map, Shipboard Scientific Party, 1993b, p. 183). The assumption that the Cretaceous carbonate structures were similar to those of modern atolls had been made because the present-day guyot topography (as seen on the seismic profiles) resembles a modern atoll in the presence of a perimeter mound and a sunken lagoon (capped by pelagic sediments). Moreover, as seen on the seismic sections, the external part of the platform carbonate deposits are relatively poorly stratified, compared to those from the inside of the guyot, and in this regard, the outer sediments resemble those of modern reefs and the inner sediments those of a lagoon (Shipboard Scientific Party, 1993b, p. 192, see also van Waasbergen, 1993, p. 64-65).

It, therefore, was anticipated that the material from Sites 866,867 , and 868 would produce a high density of rudists and/or corals to form a framework. In fact, no examples of rudist or coral framework facies were drilled (although it is conceivable that they exist, but that this facies was not recovered). Rudists were common only at two main levels in Resolution Guyot: one at the top (Holes 867/868), at least 70 $\mathrm{m}$ thick; one at a deeper level (Hole 866A), about $60 \mathrm{~m}$ thick. Beds where rudists are a major component of the microfacies, therefore, represent less than $8 \%$ of the stratigraphic column for Resolution Guyot at Hole 866A (Fig. 1 and Shipboard Scientific Party, 1993b, p. 194). The rudists are sediment-supported and do not form a skeletal framework. The forms present are almost exclusively caprinids, most of which are small to medium in size, weakly coiled, smooth-shelled forms that are not best suited for constructing a reef framework (Kauffman and Johnson, 1988).

Rudists are significant constituents of four facies at Resolution and Allison Guyots:

1. The numerous examples of the small requienid Requienia aff. migliorinii came from Allison Guyot, Hole 865A, Subunit IIIA. The specimens are preserved a few centimeters apart not far from their life position. Their upper valve (LV) has not been preserved and must have been washed away by weak currents, the lower valve (RV) remaining in the mud, anchored by its corkscrew like shape, a shellsubstrate relationship well-documented in helicospiral requieniids (Masse, 1979). These requieniids have been preserved in a wackestone, along with high-spiraled gastropods, benthic foraminifers, rare corals, and rare planktonic foraminifers. The environment represented is of a muddy, quiet-water, inner-platform environment as expected for Hole $865 \mathrm{~A}$, which was drilled near the center of Allison Guyot (Shipboard Scientific Party, 1993a, Fig. 5, p. 120). Other examples of Requienia migliorinii generally are recorded from this type of environment and tend to occur in monospecific communities (e.g., in the Mediterranean area in Barremian-Aptian sediments; Masse, 1976; Luperto Sinni and Masse, 1986 and in El Abra, Mexico, in Albian sediments; Johnson et al., 1986).

2. Petalodontia from Resolution Guyot, Hole 866A, Core 131, from Subunit VIIA is bivalved, and, therefore, presumably in its life position. The LV is approximately conical in shape. The sediment is a brown wackestone to grainstone, with peloids, ooids, blackened intraclasts, bivalve fragments, algal-encrusted gastropods, oncoids, benthic foraminifers, and some serpulid worm tubes. The facies contains numerous desiccation indicators, including bird's eyes and keystone vugs and, in places, has been pervasively dolomitized. Hole $866 \mathrm{~A}$ was drilled in what is now a depression near the perimeter mound, about $1.5 \mathrm{~km}$ from Hole $867 \mathrm{~B}$, at the margin of the presentday guyot. During Barremian time, the site clearly was near an emergent island in a littoral setting (Shipboard Scientific Party, 1993b, pp. 203-207). The genus Petalodontia currently has been documented elsewhere in inner-platform settings in Barremian-Aptian sediments (Masse, 1976; Chikhi-Aouimeur, 1983).

3. The caprinids from Resolution Guyot, Hole 866A, Subunit VIB, occur in three different facies within this subunit. Core 143$866 \mathrm{~A}-92 \mathrm{R}$ yielded one form in a floatstone that contained numerous fragments of recrystallized rudists and some gastropods in a packstone matrix. This indicates a relatively high hydrodynamic energy, open marine environment. Specimens from Cores 143-866A-93R, $-94 \mathrm{R}$, and $-9 \mathrm{R} 5$ consisted of a highly porous, well-washed grainstone to rudstone consisting of rudist fragments (preserved by micritic envelopes) and numerous coated grains. The environment is of high hydrodynamic energy, in an open-marine setting, with shell banks or shoals. Core 143-866A-97R yielded two different rudists, still attached to a shell substrate and surrounded by oyster like fragments. The surrounding sediments are a packstone-grainstone having an alveolar texture (early pedogenetic) and blue clay lining voids. This facies probably also represents an open-marine environment with periods of emergence after deposition.

4. All the rudists from the top of Resolution Guyot at Holes 867B and $868 \mathrm{~A}$ come from Unit II. The facies in this unit are variable. The new coalcomanid genus was found in a coarse grainstone having dropstone cements and an alveolar structure. This is representative of an emergent storm-beach environment. "Caprina" cf. mulleri and caprinid indet. 2 (which has affinities with "Caprina" mulleri) come from floatstone and rudstone having relatively large rudist fragments in a packstone matrix. Caprinid indet. 2 is a large RV, probably in its life position. All these forms probably lived at a site not far from where they were preserved. Holes $867 \mathrm{~B}$ and $868 \mathrm{~A}$ were drilled on the outer rim of the guyot (Shipboard Scientific Party, 1993b, p. 184). The environment represented by these sediments is a high hydrodynamic energy, platform margin environment.

Thus, a range of environments is represented in deposits that now are at the margin of the guyot. This demonstrates fluctuations through time in the position of the facies belts, similar to those encountered on other (nonguyot) oceanic carbonate platforms.

\section{ACKNOWLEDGMENTS}

We thank Alan Coogan, Erle Kauffman, and Robert Scott for reviewing the manuscript; Edward Winterer for reviewing the manuscript, too, and for several useful discussions about the regional context of the guyot material; and Peter Skelton for helpful comments on the identification of some material. This research was supported by a U.S. ODP grant for N.H.M.S.

\section{REFERENCES $*$}

Alencaster, G., 1973. Una nueva especie de Toucasia en el Cretacico medio de los estados de Puebla y Oaxaca, Mexico. Paleontol. Mex., 36:1-16.

Alencaster, G., and Pantoja Alor, J., 1986. Coalcomana ramosa (Boehm) (Bivalvia, Hippuritacea) del Albiano Temprano del Cerro de Tuxpan, Jalisco. Bol. Soc. Geol. Mex., 47:33-46.

\footnotetext{
"Abbreviations for names of organizations and publications in ODP reference lists follow the style given in Chemical Abstracts Service Source Index (published by American Chemical Society).
} 
Boehm, G., 1898. Über Caprinidenkalke aus Mexiko. Z. Dtsch. Geol. Gesell., 50:323-333.

Chikhi-Aouimeur, F., 1983. Étude paléontologique de quelques Rudistes de l'Aptien supérieur du Djebel Ouenza (Algérie Nord-Orientale). Geol. Mediter., 10:33-48.

Coates, A.G., 1973. Cretaceous Tethyan coral-rudist biogeography related to the evolution of the Atlantic Ocean. Spec. Pap. Palaeontol., 12:169-174.

Coogan, A.H., 1973. New rudists from the Albian and Cenomanian of Mexico and adjacent South Texas. Rev. Inst. Mex. Petrol., 5:51-83.

1977. Early and Middle Cretaceous Hippuritacea (rudists) of the Gulf Coast. In Bebout, D.G., and Loucks, R.G. (Eds.), Cretaceous Carbonates of Texas and Mexico: Applications to Subsurface Exploration. Rep. Invest.-Univ. Tex. Austin, Bur. Econ. Geol., 89:32-70.

d'Orbigny, A., 1848. Paléontologie Française. Terrains Crétacés, 4.

Douville, H., 1900. Sur quelques rudistes Americains. Bull. Soc. Geol. Fr. 28:205-221.

- 1918. Le Barrémien supérieur de Brouzet: Part III, Les Rudistes. Mem. Soc. Geol. Fr., Paleontol. Mem. 52, 22:1-28.

Douvillé, H., and O'Gorman, G., 1933. Le Pic de Rébenacq. Bull. Soc. Geol. Fr. Ser. 5, 3:281-320.

Goldfuss, A., 1838. Petrafacta Germaniae, 2, Dusseldorf.

Hamilton, E.L., 1956. Sunken islands of the Mid-Pacific Mountains. Mem.Geol. Soc. Am., 64.

Harris, G.D., and Hodson, F., 1922. The Rudistids of Trinidad. Palaeontogr. Am., 1:119-162.

Heezen, B.C., Matthews, J.L., Catalano, R., Natland, J., Coogan, A., Tharp, M., and Rawson, M., 1973. Western Pacific guyots. In Heezen, B.C., MacGregor, I.D., et al., Init. Repts. DSDP, 20: Washington (U.S. Govt. Printing Office), 653-723.

Ishii, T., 1985. Preliminary dive reports on Kaiko Leg 3 (Nautile, Dive 57), IFREMER, 216-252,

Johnson, C.C., Collins, L.S., and Kauffman, E.G., 1986. Rudistid biofacies across the El Abra Formation (Late Albian[?]/Early-middle Cenomanian), Northeastern Mexico. Trans. 11th Caribbean Geol. Conf., Barbados, 1-11.

Kauffman, E.G., 1973. Cretaceous Bivalvia. In Hallam, A. (Ed.), Atlas of Palaeobiogeography: Amsterdam (Elsevier), 353-383.

Kauffman, E.G., and Johnson, C.C., 1988. The morphological and ecological evolution of Middle and Upper Cretaceous reef-building rudistids. Palaios, 3:194-216.

Luperto Sinni, E., and Masse, J.P., 1986. Données nouvelles sur la stratigraphie des Calcaires de plate-forme du Crétacé inférieur du Gargano (Italie méridionale). Riv. Ital. Paleontol. Stratigr., 92:33-66.

MacGillavry, H.J., 1937. Geology of the province of Camaguey, Cuba with revisional studies in rudist paleontology (mainly based upon collections from Cuba) [Ph.D. thesis]. Rijks Univ., Utrecht, Netherlands.

Mainelli, M., 1975. Requienia tortilis nov. sp. nell Albiano inferiore del Matese centro-meridionale e dei Monte d'Ocre (Apennino centro-meridionale). Boll. Soc. Paleontol. Ital., 14:203-215.

Masse, J.-P., 1976. Les calcaires urgoniens de Provence. Stratigraphie, Paléontologie, les environnements et leur évolution [Thèse doct. sci.]. Univ. Aix-Marseille II.

, 1979. Les Rudistes (Hippuritacea) du Crétacé inférieur. Approche paleoecologique. Geobios, Mem. Spec., 3:277-287.

, 1985. Paléobiogéographie des Rudistes du domaine péri-méditerranéen à l'Aptien inférieur. Bull. Soc. Geol. Fr., Ser. 8, 1:715-721.

1992. The Lower Cretaceous Mesogean benthic ecosystems: palaeoecologic aspects and palaeobiogeographic implications. Palaeogeogr., Palaeoclimatol., Palaeoecol., 91:331-345.
Masse, J.-P., and Philip, J., 1986. L'évolution des rudistes au regard des principaux évenements géologiques du Crétacé. Bull. Cent. Rech. Explor.Prod. Elf-Aquitaine, 10:437-456.

Masse, J.-P., and Rossi, T., 1987. Le Provincialisme Sud-caraibe à l'Aptien inférieur. Sa signification dans le cadre de l'évolution geodynamique du domaine Caraibe et de l'Atlantique central. Cretaceous Res., 8:349-363.

Matheron, P., 1842. Catalogue Methodique et Descriptifs des Corps Organisés Fossiles des Bouches-du-Rhône et Lieux Circonvoisins. Rep. Trav. Soc. Stat., Marseille, VI:81-396.

Paquier, V., 1905. Les rudistes urgoniens. Deuxième partie. II Série inverse. Soc. Geol. Fr., Paleontol., 13:49-95.

Rojas, R., Skelton, P.W., and Iturralde Vinent, M. 1992. Cuban rudist faunas revisited. 13th Caribb. Geol. Conf., Cuba, Abstracts, 21.

Ross, D.J., and Skelton, P.W., 1993. Rudist formations of the Cretaceous: a palaeoecological, sedimentological and stratigraphical review. Sedimentol. Rev., 1:73-91.

Sager, W.W., Winterer, E.L., Firth, J.V., et al., 1993. Proc. ODP, Init. Repts., 143: College Station, TX (Ocean Drilling Program).

Scott, R.W., 1981. Biotic relations in Early Cretaceous coral-algal rudist reefs, Arizona. J. Paleontol., 55:463-478.

Scott, R.W., and Gonzales Leon, C., 1991. Paleontology and biostratigraphy of Cretaceous rocks, Lampazos area, Sonora, Mexico. In Perez Segura, E., and Jacques Atalaya, C. (Eds.), Studies of Sonoran Geology. Spec. Pap.Geol. Soc. Am., 254:51-67.

Shiba, M., 1979. Geological history of the Yabe Guyot to the east of the Ogasawara Islands. Chishitsugaka Zasshi [J. Geol. Soc. Jpn.], 85:209220 .

1988. Geohistory of the Daiichi-Kashima seamount and the Middle Cretaceous eustacy. Sci. Rep. Nat. Hist. Mus., Tokai Univ., 2.

Shipboard Scientific Party, 1993a. Site 865. In Sager, W.W., Winterer, E.L., Firth, J.V., et al., Proc. ODP, Init. Repts., 143: College Station, TX (Ocean Drilling Program), 111-180.

1993b. Site 866. In Sager, W.W., Winterer, E.L., Firth, J.V., et al., Proc. ODP, Init. Repts., 143: College Station, TX (Ocean Drilling Program), 181-271.

1993c. Sites 867/868. In Sager, W.W., Winterer, E.L., Firth, J.V., et al., Proc. ODP, Init. Repts., 143: College Station, TX (Ocean Drilling Program), 273-296.

Skelton, P.W., 1982. Aptian and Barremian rudist bivalves of the New World: some Old World similarities. Cretaceous Res., 3:145-153.

, 1988. The trans-Pacific spread of equatorial shallow-marine benthos in the Cretaceous. In Audley-Charles, M., and Hallam, A. (Eds.), Gondwana and Tethys. Geol. Soc. Spec. Publ. London, 37:247-253.

Tavani, G., 1948. Fauna malacologica Cretacea della Somalia e dell Ogaden. Paleontol. Ital., 43:83-153.

, 1949. Rudiste ed altri Molluschi cretacei delle Migiurtina. Paleontol. Ital., 46:1-40.

van Wassbergen, R.J., 1993. Western Pacific guyots: summit geomorphology, sedimentology and structure of drowned Cretaceous carbonate platforms [Ph.D. dissert.]. Univ. of California San Diego, La Jolla, CA.

Young. K., 1984. Biogeography and stratigraphy of selected Middle Cretaceous rudists of southwestern North America. Mem. III Congr. Latinoamer. Paleontol., 341-360.

Date of initial receipt: 24 November 1993

Date of acceptance: 27 May 1994

Ms 143SR-207 


\section{APPENDIX}

List of gastropod, coral, hydrozoan, and bryozoan specimens collected during Leg 143

\begin{tabular}{|c|}
\hline $\begin{array}{l}\text { Core, section, } \\
\text { interval }(\mathrm{cm})\end{array}$ \\
\hline $\begin{array}{l}\text { Gastropods } \\
865 \mathrm{~A}- \\
86 \mathrm{R}-1,102-105 \\
89 \mathrm{R}-4,49-55 \\
89 \mathrm{R}-4,98-102 \\
90 \mathrm{R}-1,88-91 \\
90 \mathrm{R}-3,18-20 \\
92 \mathrm{R}-1,25-32 \\
92 \mathrm{R}-1,62-68 \\
92 \mathrm{R}-1,119-125 \\
92 \mathrm{R}-1,132-136 \\
92 \mathrm{R}-2,24-26 \\
14 \mathrm{R}-\mathrm{CC}, 10-13 \\
\text { 29R-CC, } 9-12 \\
44 \mathrm{R}-\mathrm{CC}, 20-22 \\
\text { 57R-1, 22-25 } \\
\text { 105R-1, 75-78 } \\
\text { 145R-1, 40-42 } \\
\text { 166R-4, 17-20 } \\
\text { 166R-4, 23-26 } \\
\text { 169R-2, 92-94 }\end{array}$ \\
\hline $\begin{array}{l}866 \mathrm{~B}- \\
8 \mathrm{R}-1,90-94\end{array}$ \\
\hline $\begin{array}{l}867 \mathrm{~B}- \\
4 \mathrm{R}-2,60-62 \\
4 \mathrm{R}-2,62-64 \\
4 \mathrm{R}-3,36-43 \\
4 \mathrm{R}-3,58-62 \\
4 \mathrm{R}-3,67-73 \\
4 \mathrm{R}-4,10-17 \\
8 \mathrm{R}-1,16-36 \\
\end{array}$ \\
\hline
\end{tabular}

\begin{tabular}{|c|}
\hline $\begin{array}{l}\text { Core, section, } \\
\text { interval }(\mathrm{cm})\end{array}$ \\
\hline $\begin{array}{l}\text { Other bivalves } \\
866 \mathrm{~A}- \\
158-2,37-43 \\
866 \mathrm{~B}- \\
4 \mathrm{R}-2,50-54 \\
4 \mathrm{R}-3,37-43 \\
8 \mathrm{R}-1,16-33\end{array}$ \\
\hline $\begin{array}{l}\text { Corals } \\
866 \mathrm{~A}- \\
142 \mathrm{R}-1,11-13 \\
142 \mathrm{R}-1,134-137 \\
161 \mathrm{R}-1,53-58\end{array}$ \\
\hline $\begin{array}{l}867 \mathrm{~B}- \\
4 \mathrm{R}-3,67-73 \\
4 \mathrm{R}-4,27-39 \\
8 \mathrm{R}-1,42-46\end{array}$ \\
\hline $\begin{array}{l}868 \mathrm{~A}- \\
4 \mathrm{R}-2,61-62\end{array}$ \\
\hline $\begin{array}{l}\text { Sclerosponges/ } \\
\text { Milleporoids(?) } \\
866 \mathrm{~A}- \\
131 \mathrm{R}-1,76-79 \\
142 \mathrm{R}-2,30-32 \\
142 \mathrm{R}-2,45-47 \\
142 \mathrm{~A}-2,50-52 \\
142 \mathrm{R}-2,60-62 \\
149 \mathrm{R}-2,35-37 \\
150 \mathrm{R}-3,57-59 \\
\text { 150R-3, 86-89 }\end{array}$ \\
\hline $\begin{array}{l}\text { Bryozoans } \\
866 \mathrm{~A}- \\
160 \mathrm{R}-1,29-34\end{array}$ \\
\hline
\end{tabular}



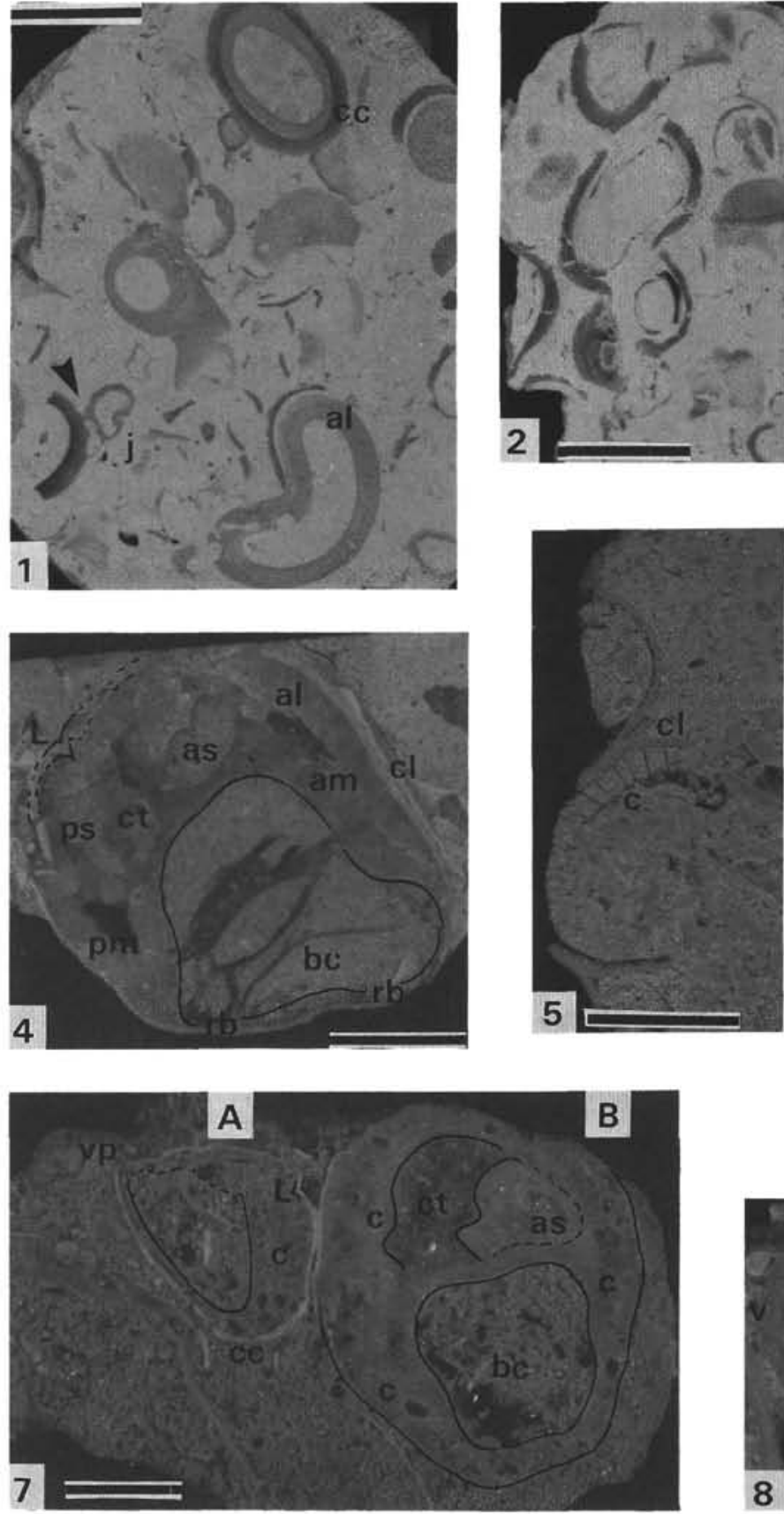

Plate 1. 1. Requienia cf. migliorinii Tavani, Allison Guyot (Sample 143-865A-28R-CC, $1-4 \mathrm{~cm}$ ). Randomly orientated sections of the left valve (LV) (attached valve) showing the outer shell layer (cc) (brown, preserved as original prismatic calcite) and inner shell layer (al) (originally aragonitic now recrystallized to sparry calcite in this specimen). $J$ marks the position of two whorls of a juvenile specimen, which is attached to a fragment of an outer shell layer. 2. Requienia cf. migliorinii Tavani, Allison Guyot (Sample 143-865A-28R-1, 61-64 cm). Longitudinal, oblique sections of a LV showing the helicospiral form. 3. Requienia cf. migliorinii Tavani Allison Guyot (Sample 143-865A-28R-1, 61-64 cm). 4. Petalodontia(?) sp. Resolution Guyot (Sample 143-866A-131R-1, 80-84 cm). Transverse section of right (attached) valve. $\mathrm{L}=$ ligamentary crest; $\mathrm{cl}=$ calcitic outer layer; $\mathrm{ct}=$ central tooth; as $=$ anterior socket; $\mathrm{ps}=$ posterior socket; bc = body cavity; $\mathrm{rb}=$ radial bands; am = anterior myophore; $\mathrm{pm}=$ posterior myophore. 5. Caprina $\mathrm{sp} .1$, Resolution Guyot (Sample 143-866A-94R-1, 16-19 cm). Transverse section of right (attached) valve-showing the simple posterior radial partitions forming canals (c) and the outer calcitic layer (cl). 6. Caprina sp. 1, Resolution Guyot (Sample 143-866A-95R-1, 27-30 cm). Transverse section of right (attached) valve showing the anterior accessory cavity (ac); posterior canals (c) are poorly preserved. $b c=$ body cavity. 7. Resolution Guyot (Sample 143-866A-97R-1, 27-30 cm). (A) Caprina(?) sp. 2. Transverse section of right valve showing well developed canals (c) on the dorsal side. Outer calcitic layer (cc) clearly visible, ventral/posterior (vp) articulation broken. $\mathrm{L}=$ ligamentary crest. $(8) \mathrm{Caprinid}$ indet. 1. Transverse section of right valve. $\mathrm{ct}=$ central tooth; as $=$ anterior socket (the corresponding tooth is preserved in situ); $\mathrm{c}=\mathrm{canals;}$ bc $=$ body cavity. 8. Caprina () ? sp. 2. Resolution Guyot (143-866A-97R-1, 36-38 cm). Oblique section of right valve showing the body cavity (bc), canals (c) and the ventral side (v) without canals. 9. Caprina(?) sp. 2. Resolution Guyot (Sample 143-866A-97R-1, 36-38 cm). Transverse section of right valve showing the asymetric shape. Anterior (a) flat, posterior (p) rounded outline. $b c=$ body cavity. 10. Caprinid fragment of questionable affinity. Resolution Guyot (Sample 143-866A-93R-1, 1-3 cm). Canals (c) preserved as internal filling (the original aragonite was dissolved). Scale bar $=1 \mathrm{~cm}$. 

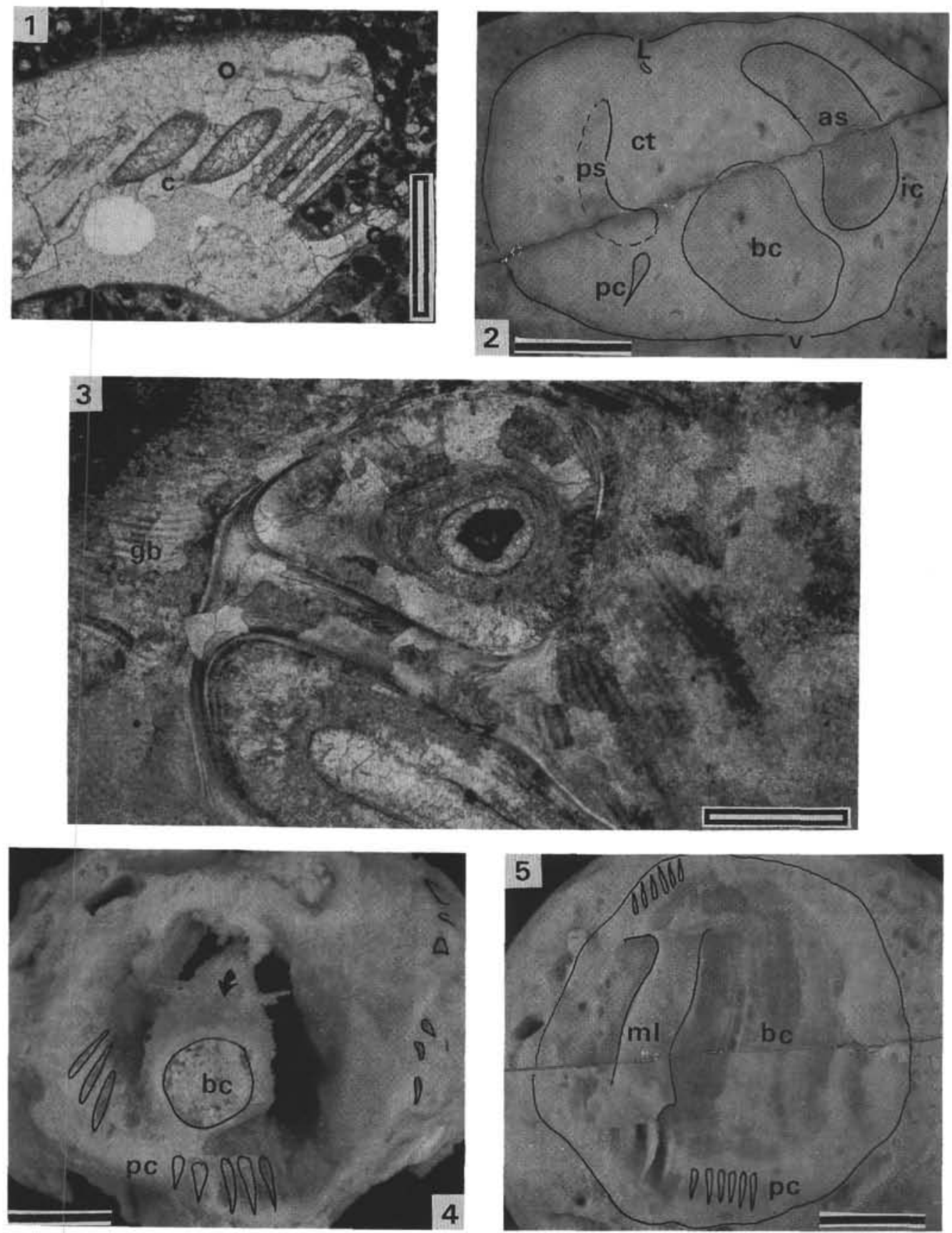

Plate 2. 1. Caprinid fragment of questionable affinity. Resolution Guyot (Sample 143-866A-92R-1, 16-19 cm). Thin section showing the pallial canals (c) outlined by a micritic coating. 2. Coalcomanid indet. 1. Resolution Guyot (Sample 143-868A-4R-1, 94-100 cm). Transverse section of right (attached) valve. $\mathrm{L}=$ ligamentary groove; $\mathrm{ct}=$ central tooth protruding posteriorly; $a$ s $=$ anterior socket; $\mathrm{ps}=$ posterior canals; $\mathrm{pc}=$ pyriform canals; $\mathrm{v}=$ ventral side without canals 3. Magnified view (thin section) of the coalcomanid indet. 1 from Figure 2 showing the shape of canals and their crystalline filling. Shell structure mainly preserved in aragonite with banded structure interpreted as growth bands (gb). 4. "Caprina" cf. mulleri. Resolution Guyot (Sample 143-868A-IR-1, 134-140 cm). Transverse section of left valve showing the body cavity (bc). Pyriform canals (pc), arrow points out the anticlockwise coiling direction, diagnostic of a left valve. 5. "Caprina" cf. mulleri. Resolution Guyot (Sample 143-868A-5R-1, 60-61 cm). Transverse section with empty body cavity (bc) showing a ledge (ml). Interpreted as a myophoral support (possible left valve). $\mathrm{pc}=$ pyriform canals. Scale bar $=1 \mathrm{~cm}$; for photomicrographs, $1 \mathrm{~mm}$. 

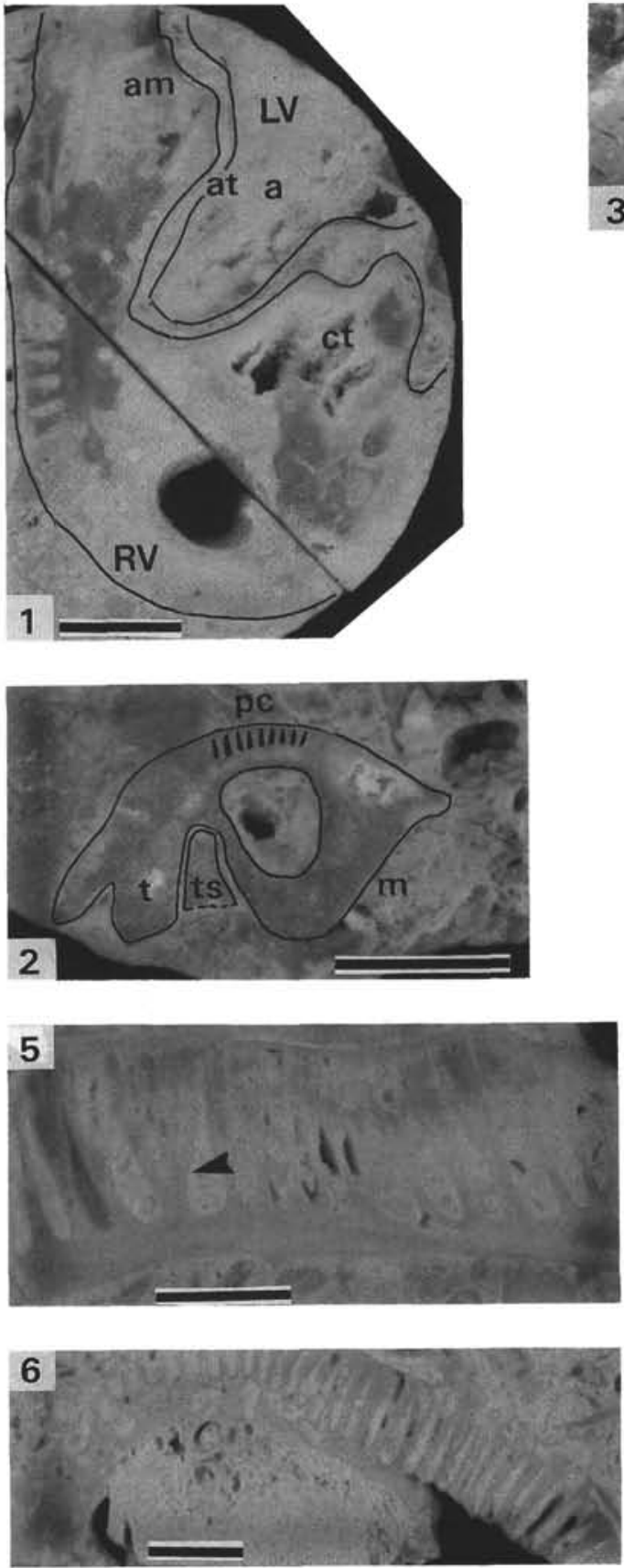
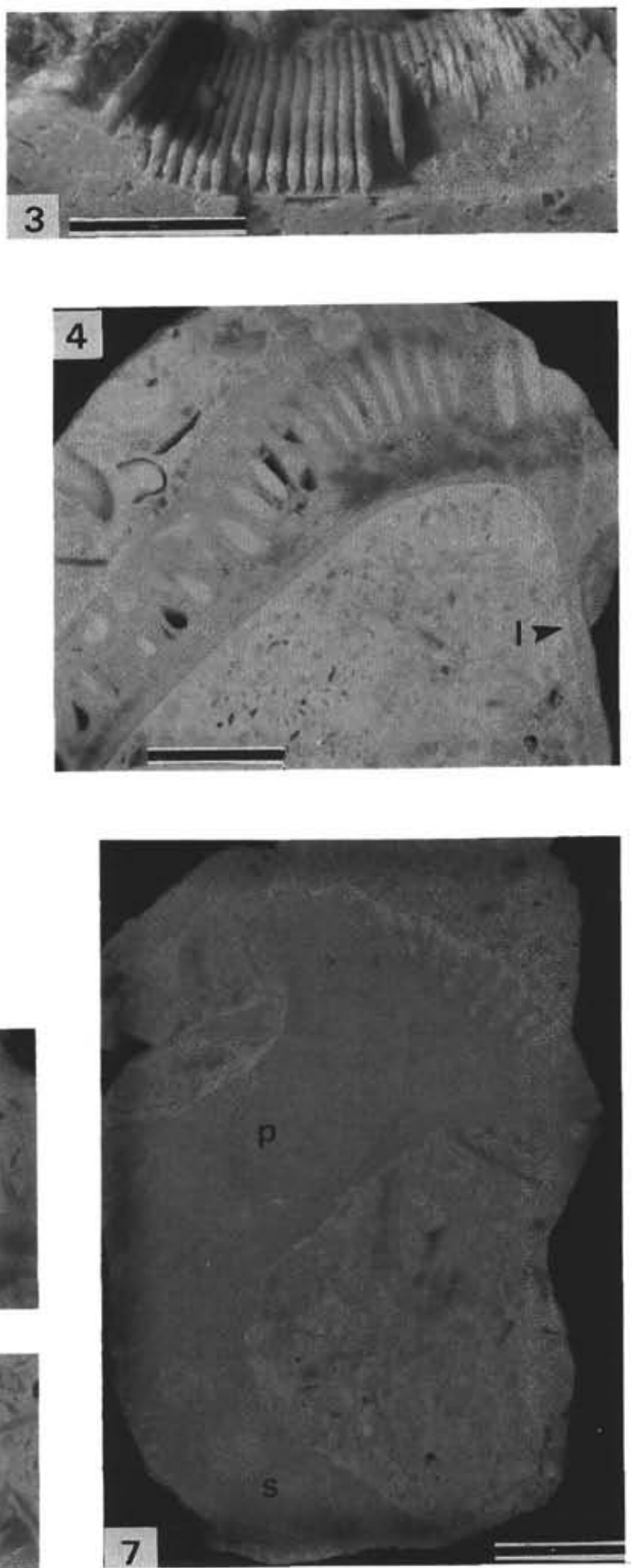

Plate 3. 1. "Caprina" cf. mulleri. Resolution Guyot (Sample 143-868A-4R-2, 98-102 cm). Oblique section of right valve showing cardinal organization and canal system. $\mathrm{bc}=$ body cavity; at = anterior tooth of the left valve in situ in the corresponding socket of right valve; $\mathrm{ct}=\mathrm{central}$ tooth; am = anterior myophore; $\mathrm{RV}=$ right valve; $\mathrm{LV}=$ left valve. 2. "Caprina" cf. mulleri. Resolution Guyot (Sample 143-868A-4R-1, 7-9 cm). Oblique section of a right valve. $t=$ tooth; ts = tooth and socket of the opposite valve; $m=$ myophore; $\mathrm{pc}=$ pyriform canals on ventral side. 3. "Caprina" cf. mulleri. Resolution Guyot (Sample 143-868A-4-1, 105-107 $\mathrm{cm}$ ). Pallial canals preserved as molds, showing in transverse section a pyriform habit. 4. Caprinid indet. Resolution Guyot (Sample 143-867B-1R-1, 80-95 cm). Transverse section of a left valve with narrow lamina (1). 5. Caprinid indet. 2. Resolution Guyot (Sample 143-867B-2R-1, 89-103 cm). Transverse section of shell wall showing the pyriform canals with some bifurcations (arrow). 6. Caprinid indet. 2. Resolution Guyot (Sample 143-867B-2R-1, 89-103 cm). Transverse section of the shell wall showing the dominance of pyriform canals. 7. Caprinid indet. 3. Resolution Guyot (Sample 143-867B-1-2, 87-90 cm). Section of a large fragment showing a thick internal partition (p) and a portion of the shell without canals (s). Scale bar $=1 \mathrm{~cm}$. 